\title{
Fatal Myiasis Caused by Calliphora vicina in Hermann's Tortoise (Testudo hermanni)
}

\author{
Z. KNOTEK $^{1}$, O. A. FISCHER ${ }^{2}$, V. JEKL ${ }^{1}$, Z. KNOTKOVÁ ${ }^{1}$ \\ ${ }^{1}$ Avian and Exotic Animal Clinic, Faculty of Veterinary Medicine, \\ University of Veterinary and Pharmaceutical Sciences Brno \\ ${ }^{2}$ Boří 3, Brno - Útěchov \\ Received October 6, 2004 \\ Accepted March 3, 2005
}

\begin{abstract}
Knotek Z., O.A. Fischer, V. Jek1, Z. Knotková: Fatal Myiasis Caused by Calliphora vicina in Hermann's Tortoise (Testudo hermanni) Acta Vet. Brno 2005, 74: 123-128.

An extensive myiasis was observed in an adult male Hermann's tortoise (Testudo hermanni) with a missing distal part of the right forelimb and an exposed right humerus. Haematological examinaton indicated very low haemoglobin levels $(37.00 \mathrm{~g} / \mathrm{l})$, low packed cell volume $(\mathrm{PCV}=$ $0.17 \mathrm{l} / \mathrm{l})$, significant leucopenia $(\mathrm{WBC}=2.75 \mathrm{G} / 1)$, an extremely low glucose concentration $(0.64$ $\mathrm{mmol} / \mathrm{l})$, hyperuricaemia $(519.9 \mu \mathrm{mol} / \mathrm{l})$, and a high ALP $(30.10 \mu \mathrm{kat} / \mathrm{l})$. Forty-three blowfly larvae were removed from the wound with a pair of foceps, using a lavage with saline and lowconcentration povidone-iodine solution. The remaining part of the humerus was surgically dissected from the humeral girdle. Necrotizing edges were removed and the opening to the body cavity was closed with sutures. After the surgery was completed, the tortoise responded poorly to external stimuli and died 12 hours after the surgery. A post-mortem examination of the body cavity revealed only an enlarged, ochre coloured liver and no pathological changes could be detected in the other organs. A histological examination diagnosed steatosis and toxic necrosis of the hepatic parenchyma. Twenty-three larvae were kept on $20 \mathrm{~g}$ of beef at room temperature. Twenty puparia were available after 7 days. After 20 - 21 days, 19 fly imagoes ( 5 females, 14 males) were obtained and identified on the basis of their morphological features as the blowfly (Calliphora vicina Robineau-Desvoidy, 1830; Diptera: Calliphoridae). It is the first case of fully documented fatal reptile myiasis in the Czech Republic.
\end{abstract}

Reptiles, hepatodystrophy, intoxication, Diptera, Calliphoridae

Although cases of wound infestation with fly larvae have been reported in humans as well as many animal species including reptiles (Jacobson 1983; Delhaes et al. 2001; Frye 1991), there have been only few papers dealing in detail with the scope of host tissue impairment (Barnard and Durden 2000; Sales et al. 2003). There is only a limited amount of information on exact taxonomic classification of agents causing myiasis in reptiles available (Barnard and Durden 2000). Myiasis caused by blowfly larvae (Lucilia ampullacea, Villeneuve) in tortoise Testudo graeca in Italy has been described (Principato and Cioffi 1996). The larvae were found in a fold of healthy skin under the carapace next to the wounded leg. The maturation of the larvae from the first to the third stage took 3 days (at a temperature of $29^{\circ} \mathrm{C}$ and relative air humidity of $80 \%$ ) (Principato and Cioffi 1996). Myiasis in two Testudo hermanni tortoises caused by Calliphora vicina blowfly larvae in Spain has been reported by Sales et al. (2003). Both blowfly species occur in the Czech Republic including Brno and surroundings (F is cher 2000). Larvae of some fly species mature in foodstuffs, others on animal waste, in wounded parts of animal bodies, or on animal cadavers. Blowfly females depositing eggs on skin, natural body openings or wounds cause myiasis. Eggs are deposited in the host body and their development is fast. According to Anderson (2000), the maturation from egg to the first stage takes between $22.5 \pm 0.2$ hours to $36.0 \pm 4.0$ hours and the whole life cycle from egg to imago stage between

Phone: +420 $54156 \ldots \ldots \ldots$

Fax:

E-mail:knotekz@vfu.cz

http://www.vfu.cz/acta-vet/actavet.htm 
$514.0 \pm 3.7$ hours and $572.0 \pm 10.0$ hours (approximately 22.1 to 23.8 days). It is not possible to prevent flies from invading wounded parts of bodies of free-living animals or to provide full protection. Especially meat residues that might attract flies must be removed. It is not easy for animal-keepers to discover the yellowish eggs or the first stage larvae, which are only $2 \mathrm{~mm}$ long and burrow into the host skin immediately after development. The second stage larvae are larger (up to $1 \mathrm{~cm}$ ) and; the hind parts of their bodies with respiratory holes (spiracles) protrude from the skin. They smell of ammonia. The third stage larvae are over $3 \mathrm{~cm}$ long and leave the host before pupation to seek out hidden dry places where they can pupate. The genuine pupa remains protected with the stripped larval skin and the whole barrel-shaped formation is called puparium. Newly emerged imagoes do not attack the host organism.

This paper brings a detailed description of a case of myiasis in a wounded Hermann's tortoise, including exact classification of flies bred from the larvae sampled. Mechanisms by which the larvae could have seriously impaired the health status of the host and cause its death are discussed.

\section{Materials and Methods}

The patient and the trauma

The patient was an adult male tortoise (Testudo hermanni), kept by a private keeper for 4 years. Considering the size of the body, the weight $(0.63 \mathrm{~kg})$ and the structure of the carapace, the tortoise was estimated to be over 10 years old. The animal had been kept in an open-air pen since the beginning of May (when he woke up from hibernation). Its health was checked every two or three days. The tortoise was offered at the clinic with a trauma of the right forelimb on 27 May 2004. A clinical examination revealed the loss of the distal part of the right forelimb with exposure of the cranial part of the humerus and a loss of corresponding muscle tissue (Plate VII, Fig. 1). There was a large wound in the skin from which a forelimb bone stump was protruding. A more detailed inspection of this unnatural body opening revealed a big, grey-white, fluid mass consisting of fly larvae bodies (Plate VII, Figs 2 and 3). The tortoise showed signs of mild dehydration and apathy. After taking a blood sample from the vena coccygea dorsalis and X-ray pictures, a surgery was started.

After intubation, the anaesthesia with an isoflurane/oxygen mixture $(5 \%$ isoflurane for induction during 5 minutes and; $3 \%$ after the surgical stage of anaesthesia was reached) was started. The surroundings of the wound were surgically cleaned, washed, and disinfected with chlorhexidine (Nolvasan Spray). A total of 43 grey-white fly larvae were removed from the opening leading into the body cavity, using a pair of forceps in combination with lavage with saline and $0.1 \%$ povidone-iodine solution (Betadine). Twenty of the extracted larvae were killed; twenty-three larvae were selected to finish their development into imagoes (Plate VIII, Fig. 4). The remaining part of the humerus was surgically removed. The isolflurane flow was discontinued and the patient was maintained on oxygen only. Necrotizing edges were removed and the opening into the body cavity was sutured (Vicryl 3).

Before the opening was closed, an antibiotic solution was applied to the lesion (Ampicilin inj. Biotika $0.5 \mathrm{~g}$ in 5 $\mathrm{ml}$ of saline). After the surgery was completed, enrofloxacin $(10 \mathrm{mg} / \mathrm{kg}$, Baytril $2.5 \%$ inj.) was injected intramusculary in the right foreleg. After 20 minutes the patient was extubated and after spontaneous respiration was resumed, the patient was moved to a clean vivarium strewed with paper only and kept at $25-30{ }^{\circ} \mathrm{C}$. The tortoise responded to external stimuli very poorly. After 12 hours the tortoise died. An autopsy was performed.

Causal agents of myiasis

During surgery, the twenty-three larvae were moved to a plastic jar $20 \mathrm{~cm}$ high and $10 \mathrm{~cm}$ in diameter. The bottom of the jar was covered with absorbent paper on which a piece of beef was placed $(20 \mathrm{~g})$. The jar was placed in a larger container with diameter and height of $30 \mathrm{~cm}$ and $10 \mathrm{~cm}$, respectively. The bottom of this container was also covered with absorbent paper. The larvae were bred on the meat in open containers at room temperature in a closed room so that no other fly species could lay eggs onto the meat. The meat was replaced by fresh meat on Day 3 . The puparia were moved to a new plastic jar with absorbent paper, which was closed with cloth. The jar was put in a room with temperature ranging between 16 and $20^{\circ} \mathrm{C}$ and high relative air humidity $(80 \%)$. The flies were counted, killed with ethyl acetate vapour and determined according to their characteristic morphological features (Schumann 1965; Rognes 1991; Barnard and Durden 2000).

\section{Results}

Flies

Myiasis in this tortoise was caused by blowfly larvae (Calliphora vicina RobineauDesvoidy, 1830; Diptera: Calliphoridae). Twenty-three larvae bred on beef produced 20 
puparia after 7 days. The first imagoes started to emerge after Day 20 days. All emerged blowflies got coloured and their body surface got hard on Day 21 . The total of 19 C. vicina imagoes emerged within 20 to 21 days, of which 5 were females and 14 males (Plate VIII, Fig. 5).

\section{Blood test results}

Blood test results and corresponding physiological values are listed in Table 1 . The patient had very low haemoglobin and PCV and major leucopenia, an extremely low glucose concentration, hyperuricaemia, and high ALP. The data indicate impairment of the hepatic parenchyma.

\section{Post-mortem examination}

A detailed examination of the body cavity and all organs eliminated mechanic damage and impairment of the organs. Most organs showed no change in colour, size or structure. One dead larva was found loose in the body cavity. The surroundings of the lesion were found to differ in colour and muscle tissue structure. The muscle tissue was soft and light grey. Vegetable dietary residues in different stages of digestion were found in the stomach and the intestine. A significant enlarged (hepatomegaly) and ochre coloured liver with dark dots (of pigment) was recorded. The edges of hepatic lobes were rounded. Histological examination confirmed steatosis and toxic necrosis of the hepatic parenchyma.

Table 1. Haematology and plasma biochemistry for male Hermann's tortoise

\begin{tabular}{|c|c|c|c|c|c|}
\hline \multirow{2}{*}{ Indices } & \multirow{2}{*}{ Units } & \multirow{2}{*}{$\begin{array}{c}\text { Patient } \\
\text { T. hermanni }\end{array}$} & \multicolumn{3}{|c|}{ Healthy tortoises $* T$. hermanni } \\
\hline & & & $\min$. & $\max$. & mean \\
\hline Hemoglobin & $\mathrm{g} / \mathrm{l}$ & 37.00 & 37.30 & 80.70 & 62.10 \\
\hline PCV & $1 / 1$ & 0.17 & 0.25 & 0.40 & 0.32 \\
\hline RBC & $\mathrm{T} / 1$ & 0.54 & 0.47 & 1.36 & 0.77 \\
\hline WBC & $\mathrm{G} / 1$ & 2.75 & 6.00 & 16.00 & 10.90 \\
\hline Lymphocytes & $\begin{array}{l}\mathrm{G} / 1 \\
\%\end{array}$ & $\begin{array}{c}0.47 \\
17\end{array}$ & 12 & 64 & $\begin{array}{c}- \\
34.7\end{array}$ \\
\hline Monocytes & $\begin{array}{c}\mathrm{G} / 1 \\
\%\end{array}$ & $\begin{array}{l}0.17 \\
6 \\
\end{array}$ & - & $\begin{array}{r}- \\
10 \\
\end{array}$ & $\begin{array}{l}- \\
1\end{array}$ \\
\hline Heterophils & $\begin{array}{c}\mathrm{G} / 1 \\
\%\end{array}$ & $\begin{array}{l}1.81 \\
66 \\
\end{array}$ & $\begin{array}{r}- \\
12 \\
\end{array}$ & 83 & $\begin{array}{c}- \\
57.5 \\
\end{array}$ \\
\hline Basophils & $\mathrm{G} / 1$ & 0.14 & - & - & - \\
\hline Eosinophils & $\begin{array}{c}\mathrm{G} / 1 \\
\%\end{array}$ & $\begin{array}{l}0.16 \\
6 \\
\end{array}$ & - & $\begin{array}{l}- \\
5 \\
\end{array}$ & $\begin{array}{l}- \\
0.3\end{array}$ \\
\hline $\mathrm{TP}$ & $\mathrm{g} / 1$ & 28.20 & 20.0 & 75.0 & 46.0 \\
\hline Glucose & $\mathrm{mmol} / \mathrm{l}$ & 0.64 & 6.2 & 14.4 & 10.0 \\
\hline BUN & $\mathrm{mmol} / \mathrm{l}$ & 4.58 & 3.3 & 21.5 & 6.8 \\
\hline Uric acid & $\mu \mathrm{mol} / 1$ & 515.9 & 119.0 & 487.0 & 163.0 \\
\hline ALP & $\mu \mathrm{kat} / 1$ & 30.10 & 1.0 & 18.5 & 5.5 \\
\hline ALT & $\mu \mathrm{kat} / 1$ & 0.19 & 0.1 & 2.1 & 0.7 \\
\hline AST & $\mu \mathrm{kat} / \mathrm{l}$ & 6.39 & 0.3 & 8.6 & 1.6 \\
\hline CK & $\mu \mathrm{kat} / 1$ & 11.85 & - & - & - \\
\hline Calcium & $\mathrm{mmol} / \mathrm{l}$ & 2.40 & 1.50 & 4.60 & 3.00 \\
\hline Phosphorus & $\mathrm{mmol} / \mathrm{l}$ & 1.11 & 1.30 & 2.60 & 1.70 \\
\hline
\end{tabular}

*according to Lawrence and Hawkey (1986); Göbel and Spörle (1992); Knotek et al. (1999) 


\section{Discussion}

Agents causing myiasis can be determined either according to morphology of the cephalopharyngeal complexes of the larvae (Erzinçlioglu 1985) or according to morphology of spiracles at the end of the larval bodies (Ass 1957), and both these methods require laboratory preparations. Breeding the larvae on meat and classifying the developing imagoes is a more reliable method, also more viable in the field (Schu mann 1965; Rognes 1991). The $C$. vicina blowfly caused myiasis in the male Hermann's tortoise. It is a cosmopolitan, synantropic, and wide-spread fly species (Havlík 1960; Rognes 1991). C. vicina imagoes are active throughout the year in middle Europe (S chroe der et al. 2003). The adult flies lick blooms, ripe fruits, honeydew produced by scale insects and aphids, fermented sap, and fruit juices. They also sit on faeces, vomited material, and cadavers or wounded animals. From there they fly to foodstuffs and feed, contaminating them with microorganisms present on their body surface, with their faeces and regurgitated fluid. As far as the risk of transmission of contamination agents is concerned, $C$. vicina ranks among the most dangerous flies ranging in Europe (Mihályi 1967).

In alternative medicine blowly larvae are used for their positive effect. Blowfly larvae may help to remove dead tissue, providing a lesion-cleaning mechanism. They secrete substances that prevent bacterial growth. That is why they are used in alternative medicine for treatment-resistant lesions (Sherman and Pechter 1988; Kočišová et al. 2001). Critics of this approach stress the risk of introduction of undesirable microflora and causing thrombosis (Nuesch et al. 2002). Barnard and Durden (2000) characterize Calliphora as facultative parasites while Cochliomyia, which are found especially in the Americas, are regarded by them as obligatory parasites. Cooper (1992) describes a method of mechanical removal of blowfly larvae from lesions in reptiles, pointing out the complicated nature of such treatment. Mechanical removal of parasitic larvae is suggested by other authors as well (Frye 1991; Barnard and Durden 2000). Lane and Mader (1996) report that although blowfly larvae may often invade free-living reptiles, they provoke more serious health problems in reptiles kept in captivity. These authors report inflammations and oedema of lesions due to the presence of fly larvae. Sales et al. (2003) have recorded the death of a female tortoise in association with myiasis in two T. hermanni tortoises. In case of massive invasion of blowfly larvae of $C$. vicina in this report involvement of the respiratory or the gastrointestinal system could be eliminated post mortem. The change of color and structure of the skeletal muscles at the site of the lesion may be due to the activity of the blowfly larvae. The change could, however, also be a consequence of the trauma of the leg, preceding the fly invasion. Only several cases of life-threatening myiasis in tortoises have been reported so far (Hinaidy and Frey 1984; Gould and Georgi 1991; Sales et al. 2003). In our case, too, despite the serious orthopaedic lesion, the patient showed no signs of the approaching death at the time of the initial examination.

Hepatomegaly and the change in colour of the hepatic parenchyma could be the result of damage due to toxic substances secreted by blowfly larvae. It is well known that blowfly larvae produce a considerable amount of ammonia, which may cause an immunosuppression of the host (Querrini 1997). It is also most important to realize that botulinum toxin has been cumulating in larval bodies (Hubálek and Halouzka 1991; Böhnel 2002). In tortoises kept in captivity at low temperatures throughout winter (hibernation), health problems connected with serious hepatic damage occur in the spring. A syndrome referred to as post-hibernation anorexia (PHA) is reported in many terrestrial tortoise species every year and if intensive therapy is not applied, it may often lead to death (Frye 1991; Mc Arthur 1996; Knotek et al. 1999). An abrupt death in October of a T. hermanni female suffering from myiasis has been reported in Spain (Sales et al. 2003). Although no results of blood tests of this female tortoise are available, the death has not been ascribed to the 
preceding hibernation. Quite on the contrary, it is likely that the tortoise kept in a natural open-air pen in Spain throughout the spring and summer might have been in a very good shape by the beginning of autumn. The male Hermann's tortoise observed by us showed no features typical of patients with PHA (urinary bladder distension, empty GIT, hyperphosphatemia) either. In addition to this, dietary remains were found in the digestive system, which also eliminates long-term anorexia. However, the possibility of an effect of the preceding hibernation and the short period allowed for spring regeneration of the liver cannot be ruled out. Despite this we believe that the main cause of the toxic damage to the liver and the subsequent death of the patient was an intoxication of the organism caused by the presence of a big amount of blowfly larvae. This opinion has been partly confirmed by some haematological and biochemical values of peripheral blood of the patient. There is a lack of experimental studies dealing with these issues.

\section{Myiáza zpo̊sobená Calliphora vicina jako příčina úhynu u želvy zelenavé (Testudo hermanni)}

U dospělého samce želvy zelenavé Testudo hermanni, se ztrátou distální části pravé hrudní končetiny a obnažením pravého humeru byla pozorována rozsáhlá myiáza. U pacienta byly vkrvi zjištěny velmi nízké hodnoty hemoglobinu $(37.00 \mathrm{~g} / \mathrm{l})$, hematokritu (0.17 1/l), výrazná leukopenie $(2.75 \mathrm{G} / \mathrm{l})$, extrémně nízká koncentrace glukózy $(0.64 \mathrm{mmol} / \mathrm{l})$, hyperurikémie $(515.9 \mu \mathrm{mol} / \mathrm{l})$ a vysoká hladina ALP $(30.10 \mu \mathrm{kat} / \mathrm{l})$. Z rány bylo pomocí pinzety, výplachem fyziologickým roztokem a naředěným roztokem povidonjodidu získáno 43 šedobílých larev much. Zbývající část humeru byla oddělena po chirurgickém přerušení vazivového spojení v ramenním pletenci. Nekrotizující okraje rány byly odstraněny a vzniklý otvor do dutiny tělní byl omezen suturou. Po ukončení operace želva reagovala se sníženou intenzitou na vnější podněty, ale po 12 hodinách došlo k úhynu. Podrobné vyšetření dutiny tělní odhalilo výrazné zvětšení okrově zbarvených jater a vyloučilo mechanické narušení nebo poškození ostatních orgánů. Histologické vyšetření prokázalo steatózu a toxickou nekrózu jaterního parenchymu. Dvacet tř̉i larev bylo chováno na $20 \mathrm{~g}$ hovězího masa při pokojové teplotě. Sedmý den bylo získáno 20 puparií. Celkem se za 20 - 21 dní vylíhlo 19 imag much (5 samic, 14 samců), určených na základě morfologických znaků jako bzučivka obecná (Calliphora vicina Robineau-Desvoidy, 1830; Diptera: Calliphoridae). Jedná se o první případ podrobně dokumentované fatální myiázy u plazů v České republice.

\section{Acknowledgements}

We express our thanks for technical assistance to Professor Dr. Roman Halouzka, DrSc., Dr. Ladislav Taras and Ms. Dagmar Karešová. We would like to thank Professor Dr. Gerry M. Dorrestein for his valuable comments.

\section{References}

ANDERSON, GS 2000: Minimum and maximum developmental rates of some forensically important Calliphora (Diptera). J Forens Sci 45: 824-832

ASS, MJ 1957: K morfologii i diagnostike ličinok sinantropnych much. Čs parasitol 4: 15-52

BARNARD, SM, DURDEN, LA 2000: A veterinary guide to the parasites of reptiles. Vol. II., Krieger Publ. Comp., Malabar, 288 p.

BÖHNEL, H 2002: Household biowaste containers (bio-bins) - potential incubators for Clostridium botulinum and botulinum neurotoxins. Water, Air and Soil Pollut 140: 335-341

COOPER, JE 1992: Integument. In: BEYNON, PH, LAWTON, MPC, COPER, JE (eds.). Manual of Reptiles. BSAVA, Cheltenham, pp. 73-79

DELHAES, L, BOUREL, B, SCALA, L, MUANZA, B, DUTOIT, E, WATTEL, F, GOSSET, D, CAMUS, D, DEI-CAS, E 2001: Recovery of Calliphora vicina first-instar larvae from a human traumatic wound associated with a progressive necrotizing, bacterial infection. Amer J Trop Med Hyg 64: 159-161

ERZINÇLIOGLU, YZ 1985: Immature stages of British Calliphora and Cynomya, with a re-evaluation of the taxonomic characters of larval Calliphoridae (Diptera). J Nat Hist 19: 69-96 
FISCHER, OA 2000: Blowflies of the genera Calliphora, Lucilia and Protophormia (Diptera, Calliphoridae) in South-Moravian urban and rural areas with respect to Lucilia bufonivora Moniez, 1876. Acta Vet Brno 69: 225-231

FRYE, FL 1991: Biomedical and surgical aspects of Captive Reptile Husbandry. Krieger Publ. Comp., Malabar, $653 \mathrm{p}$.

GÖBEL, T, SPÖRLE, H 1992: Blutentnahmetechnik und Serumnormalwerte wichtiger Parameter bei der Griechischen Landschildkröte (Testudo hermanni hermanni). Tieräztl Prax 20: 231-234

GOULD, WJ, GEORGI, ME 1991: Myiasis in two box turtles. J Amer Vet Med Assoc 199: 1067-1068

HAVLÍK, B 1960: Stručný klíč k určování našich nejhojnějších synantropních much (Diptera) s ekologickými poznámkami o jejich výskytu v Praze. Čs epidemiol mikrobiol imunol 10: 272-281

HINAIDY, HK, FREY, H 1984: Weitere Fakultativmyiasis-Falle bei Wirbeltieren in Österreich. WienTierärztl Monat 71: 237-238

HUBÁLEK, Z, HALOUZKA, J 1991: Persistence of Clostridium botulinum type C in blow fly (Calliphoridae) larvae as a possible cause of avian botulism in spring. J Wldl Dis 7: 81-85

JACOBSON, ER 1983: Parasitic diseases of reptiles. In: KIRK, RW (Ed) Current Veterinary Therapy VIII. WB Saunders, Philadelphia pp. 599-605

KNOTEK, Z, KNOTKOVÁ, Z, HALOUZKA, R, MODRÝ, D, HÁJKOVÁ, P 1999: Nemoci plazů. ČAVLMZ, Brno, $275 \mathrm{p}$.

KOČIŠOVÁ, A, TOPORČÁK, J, ČONKOVÁ, E, MOLČÁNYI, T, PISTL, J, CIBUR, P 2001: Veterinárne a humánne ošetrenie kožných infekcií larvami múch. Sborník referátů Využití doplňkové a nekonvenční péče o zdraví v chovech hospodářských a domácích zvířat. České Budějovice, 3. 9. 2001, pp. 16-19

LANE, TJ, MADER, DR 1996: Parasitology. In: MADER, DR (ed.) Reptile Medicine and Surgery. WB Saunders, Philadelphia pp. 185-203

LAWRENCE, K, HAWKEY, C 1986: Seasonal variations in haematological data from Mediterranean tortoises (Testudo graeca and Testudo hermanni) in captivity. Res Vet Sci 40: 225-230

McARTHUR, S 1996: Veterinary management of tortoises and turtles. Blackwell Science Ltd., Oxford, 170 p.

MIHÁLYI, F 1966: Flies visiting fruit and meat in an open-air market in Budapest. Acta Zool Acad Sci Hung 12: 331-337

MIHÁLYI, F 1967: The danger-index of the synanthropic flies. Acta Zool Acad Sci Hung 13: 373-377

NUESCH, R, RAHM, G, RUDIN, W, STEFFEN, I, FREI, R, RUFLI, T, ZIMMERLI, W 2002: Clustering of bloodstream infections during maggot debridement therapy using contaminated larvae of Protophormia terraenovae. Infection 30: 306-309

PRINCIPATO, M, CIOFFI, A Notes on the incidence of the Lucilia genus (Diptera: Calliphoridae) in Umbria, Central Italy. A case of myiasis by Lucilia ampullacea (Villen 1922) in Testudo graeca. Proc. 20th Int Congress of Entomol, Firenze, 25. - 31. 8. 1996, p. 769

QUERRINI, VH 1997: Excretion of ammonia by Lucilia cuprina larvae supresses immmunity in sheep. Vet Immunol Immunopathol 56: 311-317

ROGNES, K 1991: Blowflies (Diptera, Calliphoridae) of Fennoscandia and Denmark. Fauna Entomol Scand 24: $5-272$

SALES, MJ, FERRER, D, CASTELLÀ, J, BORRÀS, D, HALL, MJ 2003: Myiasis in two Hermann's tortoises (Testudo hermanni). Vet Record 153: 600-601

SHERMAN, RA, PECHTER, EA 1988: Maggot therapy: a review of the therapeutic applications of fly larvae in human medicine, especially for treating osteomyelitis. Med Vet Entomol 2: 225-230

SCHROEDER, H, KLOTZBACH, H, PÜSCHEL, K 2003: Insects' colonization of human corpses in warm and cold season. Legal Med 5: S372-S374

SCHUMANN, H 1965: Die Schmeissfliegengattung Calliphora. Angw Parasitol 11: S1 - S14 
Plate VII

Knotek Z . et al.: Fatal Myiasis ... pp. 123-128

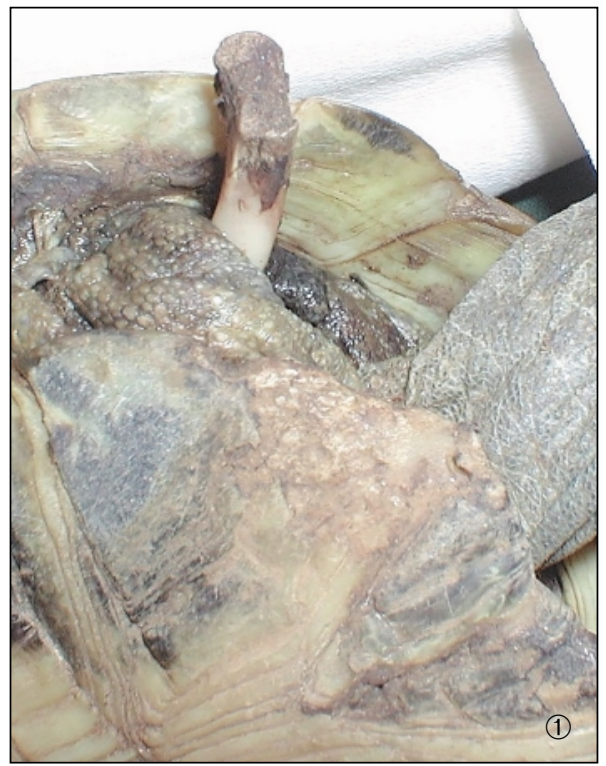

Fig. 1. The wounded right leg of a male

Hermann's tortoise before the surgical intervention

Fig. 2. Accumulation of fly larvae at the site of the traumatic lesion of the leg

Fig. 3. Demonstration of the presence of Calliphora vicina larvae during

Testudo hermanni clinical examination
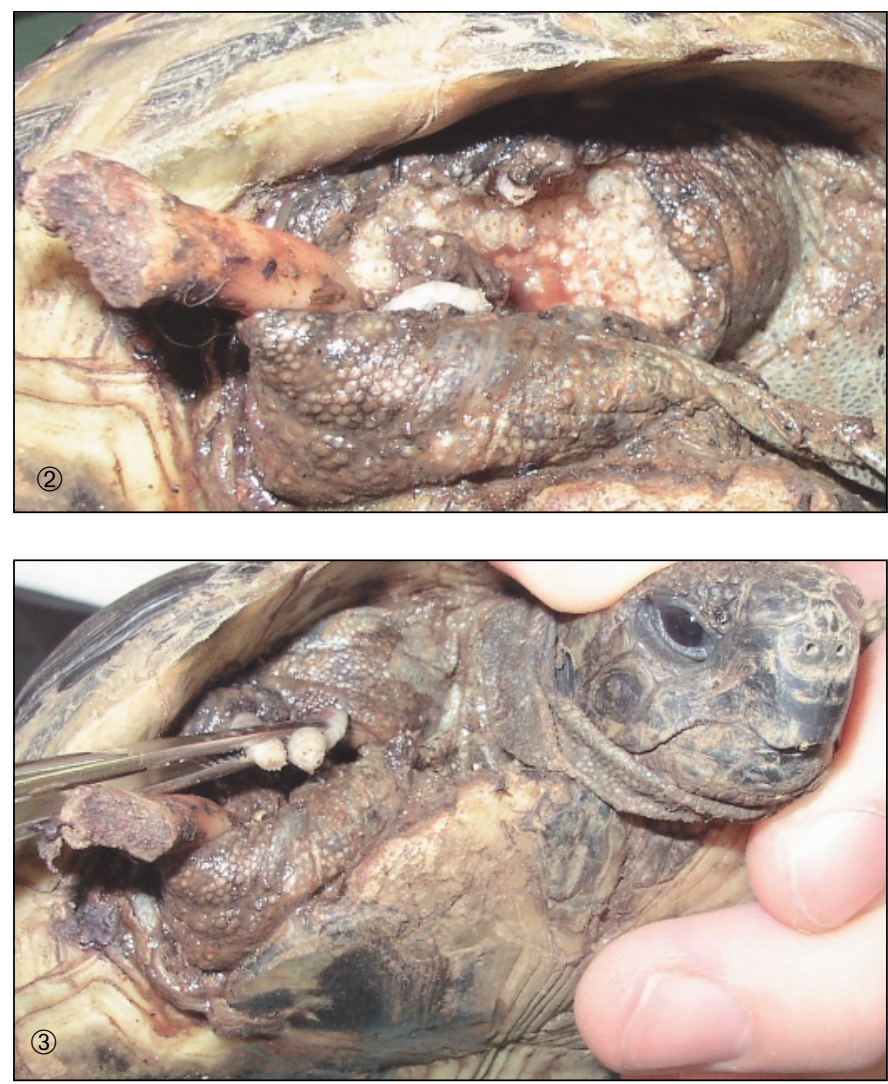


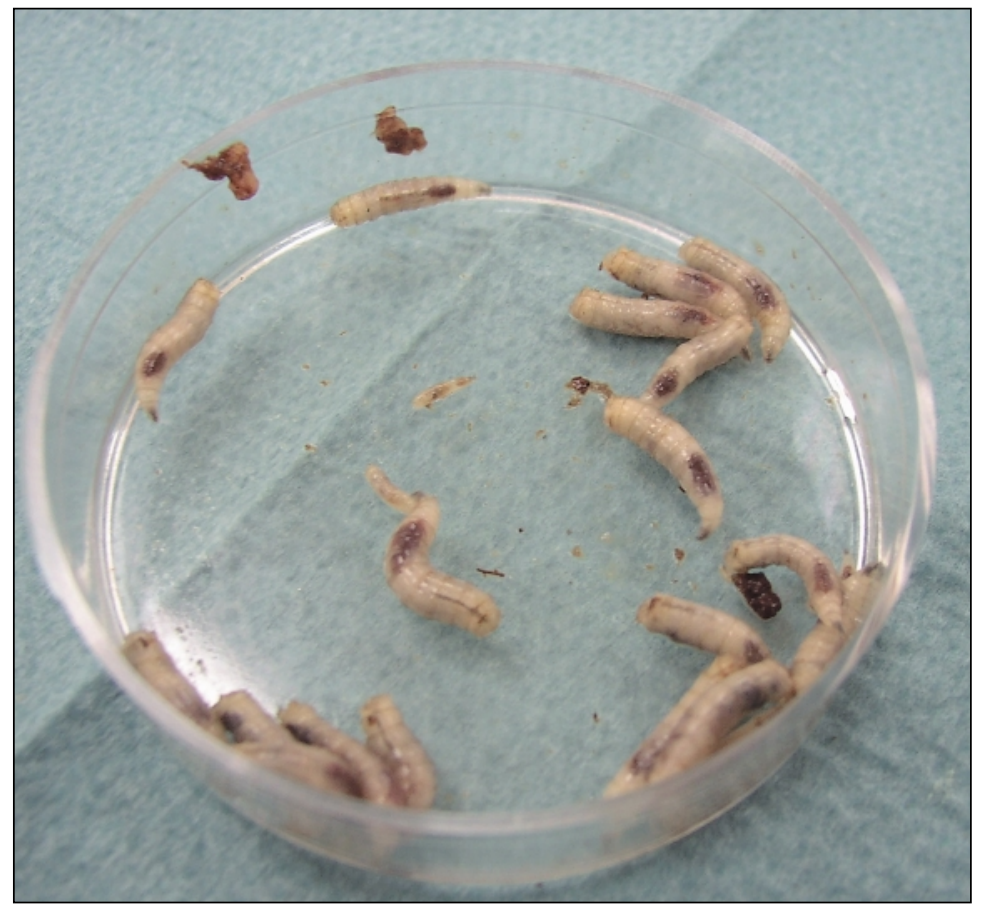

Fig. 4. Calliphora vicina larvae immediately after their removal from the lesion

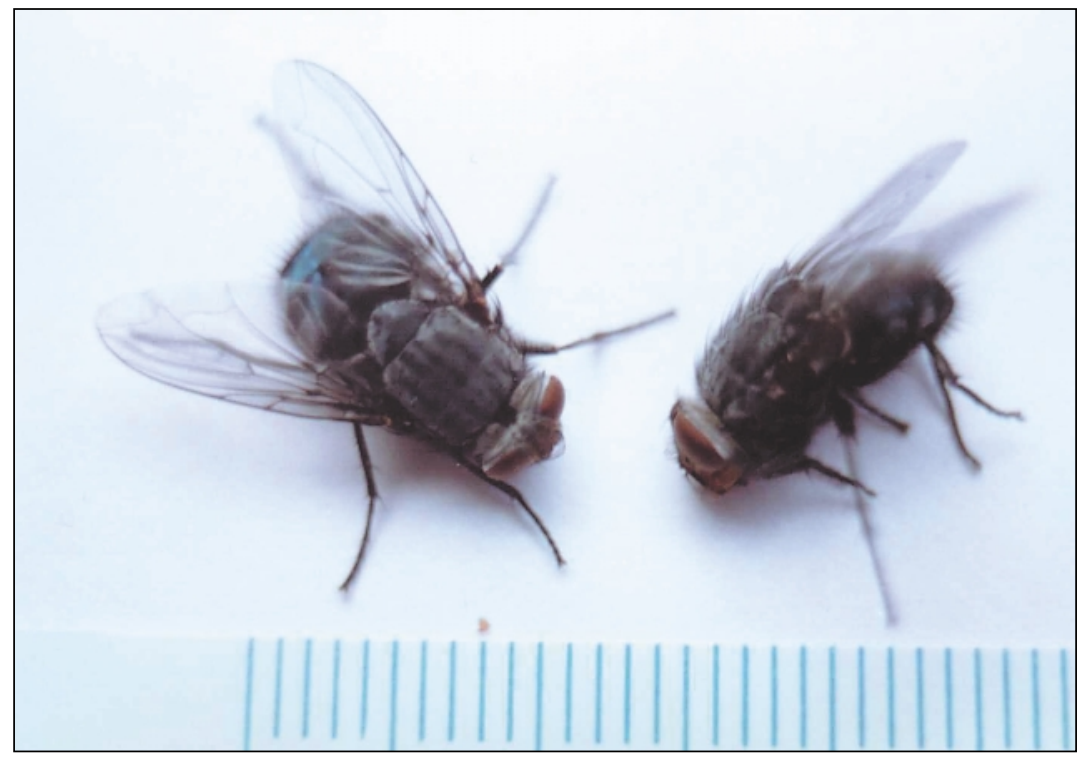

Fig. 5. Two blowfly (Calliphora vicina) imagoes obtained from 2nd stage larvae (female on the left, male on the right). Millimeter measuring scale 